\title{
Effects of two selected systemic insecticides in the management of major field insect pests of Okra (Abelmoschus esculentus L. Moench) in Enugu State, South-eastern, Nigeria
}

\author{
Omeje, T. E. ${ }^{1}$, Ezema, R. A. ${ }^{1}$, Awere, S. U. ${ }^{2}$ and Adinde, J. 0. ${ }^{*}$ \\ ${ }^{1}$ Department of Agricultural Technology, Enugu State Polytechnic, Iwollo, Enugu State, Nigeria. \\ ${ }^{2}$ Department of Agronomy and Ecological Management, Faculty of Agriculture and Natural Resources Management, \\ Enugu State University of Science and Technology, P. M. B. 01660 Enugu, Nigeria. \\ ${ }^{3}$ Department of Horticultural Technology, Enugu State Polytechnic, Iwollo, Enugu State, Nigeria. \\ *Corresponding author: Email: jonathanadinde@gmail.com
}

Copyright @ 2018 Omeje et al. This article remains permanently open access under the terms of the Creative Commons Attribution License 4.0, which permits unrestricted use, distribution, and reproduction in any medium, provided the original work is properly cited.

Received 6th March, 2018; Accepted 15th May, 2018

\begin{abstract}
Flea beetles (Podagrica spp.) have been a serious insect field pests of the family, Malvaceae or hibiscus crops most especially Okra in all growing nations. Field trial was conducted in the Department of Crop Science, University of Nigeria, Nsukka, Nigeria to determine their relative effectiveness of synthetic systemic insecticides in field management of Podagrica spp. insect pests of Okra. The experiment was laid out in Randomized Complete Block Design (RCBD) and treatments consisted of two synthetic systemic insecticides: Dimethoate 40EC and Carbofuran 5G and control with no insecticide application. Early maturing Clemenson spineless Okra variety, Jokoso was used. The results showed that there were no significant $(P>0.05)$ effects on Flea beetles population before insecticide treatments at 14 and 28 Days after planting (DAP). There was also no significant effect of insecticide application on fresh pod and dry pod weight (kg/plot) at harvest. However, significant differences $(\mathrm{P}<0.05)$ were obtained on Flea beetles population, number of infected plants (\%), fresh pod quality/marketable pods (\%) throughout the sampling periods after insecticide application and also on seed viability test after harvest (\%). In general, insecticides treated okra plants performed better than the untreated ones with Carbofuran $5 \mathrm{G}$ treated plants having the best performance.
\end{abstract}

Key words: Carbofuran 5G, Dimethoate 40EC, Flea beetles, okra, systemic insecticides.

\section{INTRODUCTION}

Okra (Abelmonschus esculentus L. Moench) belongs to the family Malvaceae (Porter, 2000). It is a warm season, tropical and temperate annual to perennial horticultural vegetable crops. Okra is of great economic importance where the immature, mucilaginous edible pods and fresh leaves are used for thickening and flavouring soup, stew and sauce. It ranks as one of the most important vegetable crops after tomatoes in Nigeria due to its high rich source of nutrients like mineral salts such as calcium, iron, potassium, sodium, vitamins ( $\mathrm{A}, \mathrm{B}_{6}$ and $\left.\mathrm{C}\right)$, carbohydrates, fats, proteins, phenols, fibres, and folic acid (Zook, 2006;
Huang et al., 2007; Araiptsas, 2008). The high fibre contents obtained in okra helps to stabilize blood sugar as it restricts the rate of sugar absorption in the intestinal tract. The fibre also absorbs water and ensures bulk in stool thereby preventing and improving constipation problem (Izuogu et al., 2011). The mucilaginous content of okra binds cholesterol together and bile acid carrying toxin and dumps it into the filtering liver. The mature stems and lignified pods produce fibre which is an Agro-allied industrial raw material for paper and textile (Kuchare and Hotchmuth, 2003). 
In most growing areas like Nigeria, okra plants are attacked mostly by flea beetles (Podagrica uniforma Jac. and Podagrica jostedti Jac.), causing both direct physical and indirect damages to crops. Flea beetles are early season occurring major field insect pests (Ezue, 1978). The larvae feed on the roots and the freshly germinated stands, whilst the adults cause many small holes in the leaves and also feed on the flowers and the developing pods (Ezue, 1978). The other great economic important host plants of flea beetle include Roselle (Hibiscus sabdariffa), kenaf (Hibiscus cannabinus), kapok tree (Ceiba pentandra), Baobab tree (Adansonia digitata), cotton (Gossypium spp) (Eberhard, 1978). The okra field yield losses are reported in Nigeria and Ghana (Ahmed et al., 2007; Obony-ofori and Sackey, 2013). The adult flea beetles together with cotton stainers, Dysdercus supersititiosus (F.) and white flies, Bemisia tabaci (Gennadius) also transmit the okra leaf mosaic virus (OLMV). Genus Tymovirus and okra leaf curl virus (OLCV) Genus Begomo virus which indirectly causes stunted growth, shrivelled pods/seeds, reduced liquid contents of seeds resulting to poor germination rate, malformed pods, seedless/empty pods and significant yield reduction (Vanlommel et al., 1996). The severe indirect damage is also caused by the transmission of fungal pathogen, Nematospora spp. and bacterial organism causing internal pod rot which may also destroy the seeds. The indirect effect may affect the viability and storability of okra seeds for future crop production (Ezue, 1978). The pesticides application is still the most powerful available measure used for pest management and therefore, are highly effective as curative agent adapted to most situation, economically low, reliable for emergency action and its usage generally reduces pest infestations and promotes yield. There is need to investigate the effectiveness of some synthetic insecticides in the field production and insect pest management of okra. This study was therefore, aimed to evaluate the effects of two selected synthetic systemic insecticides in the field management of flea beetles of okra and consequent effects on the viability of the seeds of treated okra plants after harvest.

\section{MATERIALS AND METHODS}

\section{Experimental site}

The experiment was conducted at the Department of Crop Science Teaching and Research Farm, University of Nigeria Nsukka. Nsukka lies between Coordinates (latitude $06^{\circ} 52^{\prime \prime} \mathrm{N}$ and longitude $07^{\circ} 24^{\prime \prime} \mathrm{E}$ ) with a mean elevation of 447.26 metre above sea level (Uguru, 2011). The study area is characterized by a bimodal pattern of climate (rainfall) with peaks in June and September and a short dry period between Mid-July to August (August break) (Uguru, 2011). The soil is characterized as tropical ultisol of sandy loam texture with derived tropical (humid) savannah vegetation (Nwadialor, 1989).

\section{Treatment applications}

The treatments applied in this research include Carbofuran 5G, Dimethoate 40EC, and untreated plots (control). Early maturing Clemenson spineless Okra var. Jokoso was used for the study. The Okra variety used for the study was sourced from Ministry of Agriculture, Enugu State, Nigeria.

\section{Field operations}

The experiment employed Randomized Complete Block Design (RCBD). The experimental area was cleared, ploughed, harrowed and manually laid out into four blocks as replications and three plots for the treatments, separated by $1 \mathrm{~m}$ and $0.5 \mathrm{~m}$ alley, respectively. Each plot was measured $2.25 \mathrm{~m} \times 1.8 \mathrm{~m}$ and contained plant stands at $0.45 \mathrm{~m} \times 0.6 \mathrm{~m}$ (intra $\times$ inter row spacing) giving 15 stands per plot (37037 stands/ha). Prior to bed preparation, well cured poultry manure was broadcast and incorporated into the soil at the rate of 20 tons/ha. The Okra seeds of spineless Clemenson variety were sowed at three seeds per hole and the seedlings were thinned to one plant per hole at the three leaf stage leaving the most vigorous plant per stand.

The post planting field agronomic practices include: manual weeding, supplementary application of NPK fertilizer at the rate of $35 \mathrm{~kg} / \mathrm{ha}$, mulching and irrigation. The insecticide treatments commenced at the first sign of insect infestations at 4 weeks after planting (WAP). Dimethoate 40EC was sprayed as foliar spray using EP knapsack sprayer at low volume spray application at 1.2 $\mathrm{kg}$ active ingredient (a.i)/100 litres of water/ha, while the Carbofuran 5G was applied as a single dose by straight band method at $10 \mathrm{~cm}$ away from the stand and 2.5 to 3 $\mathrm{cm}$ deep in the soil at the rate of $1.5 \mathrm{~kg}$ a.i/ha. All sprays were carried out at the calm weather during early morning hours ( 7 to $8 \mathrm{am}$ ) in order to avoid chemical drift and when the insects are less active. Also, sprays were done before flower initiation to meet up the safety periods of the insecticides and also to spare the beneficial insect pests against insecticide hazards for effective pollination processes. The field experiments lasted for 95 days after planting (DAP).

\section{Data collection}

Data were collected from five randomly selected sample stands in each plot. Data were collected on number of infected plants (\%), fresh and dry pod weights (kg/plot) at harvest, fresh pod quality/marketable pods (\%) and seed viability (\%) after harvest. The number of infected plants was determined by direct counting through physical observation. Seed viability was assessed using seed germination test. The marketable pods were selected through physical observation and were counted. The fresh and dry pod weights were determined using electronic weighing machine. 
Table 1. Effect of Carbofuran $5 G$ and Dimethoate $40 E C$ on mean flea beetle population on okra per stand at stipulated days after planting (DAP).

\begin{tabular}{lcccc}
\hline \multirow{2}{*}{ Treatments } & \multicolumn{4}{c}{ Days after planting } \\
\cline { 2 - 5 } & $\mathbf{1 4}$ & $\mathbf{2 8}$ & $\mathbf{3 5}$ & $\mathbf{4 2}$ \\
\hline Control & 34.00 & 38 & 42 & 57 \\
Carbofuran 5G & 2.25 & 39 & 2 & 5 \\
Dimethoate 40EC & 32.25 & 40 & 4 & 3 \\
F - SLD (0.05) & - & - & 1.40 & 0.08 \\
\hline
\end{tabular}

- = No significant; F - LSD Fisher's least significant differences at $5 \%$ probability level.

Table 2. Effect of Carbofuran $5 G$ and Dimethoate $40 E C$ on number of infected plants (\%) by okra mosaic virus (OMV) per plot.

\begin{tabular}{lc}
\hline Treatments & OMV Infected plants /plot (\%) \\
\hline Control & 4.25 \\
Carbofuran 5G & 2.00 \\
Dimethoate 40EC & 3.00 \\
f-LSD $(0.05)$ & 0.75 \\
\hline
\end{tabular}

$\mathrm{OMV}=$ Okra mosaic virus.

\section{Data analysis}

The data collected on the parameters were subjected to Analysis of Variance (ANOVA) test as described by Steel and Torrie (1980) using Genstat Release 10.3DE software (GenStat, 2011) and Fisher's Least Significant Difference (F - LSD) was employed to compare the treatment means where significance was observed at $5 \%$ probability level as outlined by Obi (2002).

\section{RESULTS AND DISCUSSION}

The flea beetles species, Podagrica uniforma Jecobi and Podagrica jostedti Jecobi (coleopteran:Chrysomelidae) were observed to be the major insect pests of okra leaves and fresh pods. The Flea beetles started infestation some days after germination at leaf initiation depending on environmental factors such as rainfall, humidity and temperature. The flea beetles population significantly $(\mathrm{P}<$ 0.05 ) increased to an average of 159 and $77 P$. uniforma and $P$. jostedti, respectively at 42 DAP (Table 1 ). Flea beetles were reported in most West African countries as the major insect pest of okra (Ogbalu and Ekweozor, 2002; Obeng-Ofori and Sackey, 2003; Ukoima and Oka, 2006). The other insect pests observed in small number were aphids (Aphis gossypii Glover), tobacco white flies (Bemisia tabaci Genn.), leafhopper (Empoasca fascialis), cotton strainers (Dysdercus supersititiosus F. Heteroptera: Pyrrhocoridae), blister beetles (Mylabris spp.) and grasshopper (Zonocerus variegatus L.) on different parts of okra plant. The number of beetles at 14 to 28 DAP, prior to chemical application showed no significant $(P>0.05)$ effect (Table 1). This result was in conformity with Egwuatu (1982) findings on late okra where he reported that the number of flea beetles in all okra field were not significantly different from one another during the initial insect population sampling at 14 to 28 DAP prior to chemical application. Thereafter, the treated plots were significantly different $(P<0.05)$ when compared with untreated plots. Carbofuran $5 G$ treated plots had the least significant number of flea beetles at a week after chemical application followed by Dimethoate 40EC at later stages. This suggested that frequent spray regimes should be applied for better Okra insect pest management and crop improvement.

There were significant $(P<0.05)$ differences on number of infected plant and percentage seed viability (Table 2 and $3)$. The Carbofuran treated plots showed high significant effect $(P<0.05)$ when compared with Dimethoate and control plots. This may be attributed probably to high spectrum of Carbofuran $5 \mathrm{G}$ as an insecticide, nematicide and miticide. Raros (1974) showed that soil application of Carbofuran at $2 \mathrm{~kg}$ a.i/ha to maize seedlings for management of European corn stem borer, Orstrania furnacalis Guenee provided extra protection on bean flies, Ophiomyia phaseoli. Lutsinger and Moody (1976) noted that small scale farmers prefer economical and wide spectrum pesticides that can be used on varieties of crops against a wide species of insect pests.

The result of fresh pod damage/unmarketable pods (\%) recorded a significant $(P<0.05)$ effect among the mean treatments as shown in Table 4. The untreated plots had the highest percentage mean number of unmarketable fresh pods $(68 \%)$ compared to other treatments, while the Carbofuran $5 \mathrm{G}$ treated plots had the least percentage of 
Table 3. Effect of Carbofuran $5 G$ and Dimethoate $40 E C$ on okra mean seed viability (\%) after harvest.

\begin{tabular}{lc}
\hline Treatments & Mean seed viability (\%) \\
\hline Control & 78 \\
Carbofuran $5 \mathrm{G}$ & 93 \\
Dimethoate 40EC & 95 \\
F. LSD $(0.05)$ & 8.15 \\
\hline
\end{tabular}

F-LSD $(0.05)=$ Fisher's least significant difference at $5 \%$ probability level.

Table 4. Effect of carbofuran $5 G$ and Dimethoate $40 E C$ on percentage fresh pod damage/unmarketable fresh pods.

\begin{tabular}{lc}
\hline Treatments & \%Unmarketable fresh pod \\
\hline Control & 68 \\
Carbofuran 5G & 15 \\
Dimethoate 40EC & 23 \\
F. LSD $(0.05)$ & 0.68 \\
\hline
\end{tabular}

F-LSD $(0.05)=$ Fisher's least significant difference at $5 \%$ probability level.

Table 5. Effect of carbofuran $5 \mathrm{G}$ and Dimethoate $40 \mathrm{EC}$ on fresh and dry pod weight (kg/plot) of okra at harvest.

\begin{tabular}{lcc}
\hline Treatments & Fresh pod weight (kg) & Dry pod weight (kg) \\
\hline Control & 0.05 & 0.0028 \\
Carbofuran 5G & 0.07 & 0.0039 \\
Dimethodate 40EC & 0.06 & 0.0034 \\
F- LSD $(0.05)$ & - & - \\
\hline
\end{tabular}

- = No significant, $\mathrm{Kg}=$ Kilograms, F-LSD $(0.05)=5 \%$ Probability level.

unmarketable fresh pods (15\%) at sampling periods followed by Dimethoate 40EC with $23 \%$. The least percentage mean number of damaged pods produced by Okra plants were in manifestation of more greenish and healthy nature of plants treated with Carbofuran $5 \mathrm{G}$ in the field which may be attributed to its triple actions as an insecticide, acaricide/miticide and nematicide. The result also showed high systematic action and more effective and efficacy nature of Carbofuran $5 G$ than foliar spray which may be affected by climatic factors such as rainfall, wind action and degree of air humidity. Uthamamy et al. (1977) in a field trial with okra discovered that soil application of Aldicarb and Carbofuran 5G recorded the highest percentage of good quality/marketable pods and also the least percentage of infected plants.

There were no significant $(P>0.05)$ effects of insecticide treatments on pod fresh weight and dry weight (Kg/Plot) at harvest (Table 5). However, the untreated plots had the least fresh $(0.05 \mathrm{~kg})$ and dry pod weight $(0.0028 \mathrm{~kg})$ compared to the treated plots with Carbofuran $5 \mathrm{G}$ treated plots rated highest $(0.07 \mathrm{~kg}$ fresh weight and $0.0039 \mathrm{~kg}$ dry weight). This might be due to less leaves damage and vigorous growth of Carbofuran $5 \mathrm{G}$ treated crops. This agreed with the fact that insecticides treated crops increase crop yields. The other earlier reporters maintained that pesticides treatment promotes yield increase on okra farm (Agbaje and Daramola, 2000; Anaso, 2003; Alhmed et al., 2007; Thul et al., 2009), while the rest reporters showed that there were no significant enhancements of crop yield due to insect pest management of flea beetles on okra (Emosairue and Ukeh, 1997; Odebiyi et al., 1981). Also, Ibekwe et al. (2011), reported no significant differences between insecticide treatments on mean weight of marketable leaves, fruits/pods, fruits and damaged leaves, number of vine per plant of fluted pumpkin (Telfairia occidentalis Hook). The non-significant results observed, despite the reduction of photosynthetic potential of plant leaves on untreated stands suggest that yield was attributed to an inherent/genetic characters of the crop varieties and also the only physical damages done to crop leaves by field insect pest on some crops contributes less to yield reduction due to their high tolerance to pathogens or field insect pests. However, in most studies on yield reduction 
on okra, many other insect pests such as white flies (Bemisia tabaci Genn), cotton aphids (Aphis gossypii Glov.) and cotton stainers (Dysdercus supersititiosus F.) were reported. Cotton stainers, Dysdercus supersititiosus (F) were also observed on okra at the same growing period mostly during flowering stages (Mohammed-Almed, 2000) and pod initiation showing significant impact on yield of okra. The insecticide treatments can manage many field insect pests thereby promoting high yield and seed quality of okra. Moreover, as flea beetles infestation can also spread okra leaf mosaic virus disease and shrivelled okra seed which might result to yield losses, poor seed quality and storability. Hence, checking the insect pest can lead to yield increase (Vanlommel et al., 1996) and provision of healthy and viable seeds for future planting materials.

\section{Conclusion}

The results of this study revealed that there were no clear yield losses due to massive leaf feeding of Podagrica spp insect pests of okra, despite high level of leaf damage through leaf tattered holes (perforation) and leaf scarification in the study area which could result in reduction of photosynthetic potential of the crop, reduced yield as well as vectors of other phyto - viral diseases. However, there was significant increase in the quality of fresh okra pod from okra plants treated with pesticides in terms of marketable pods with Carbofuran 5G treated plants having the superior value. The effects of Carbofuran $5 G$ and Dimethoate 40EC on okra field production have been identified to be recommended to farmers in the management of insect pests of Okra with Carbofuran 5G recording the best performance.

\section{CONFLICT OF INTEREST}

The authors declare that they have no conflict of interest.

\section{REFERENCES}

Agbaje, G. O., \& Daramola, A. M. (2002). Influence of season and Tyrax (Pyrethrum-based) insecticide on Okra (Abelmoschus esculentus (L) Moench) green capsule yield, Niger. J. pure Appl. Sci.,15, 1031-1036.

Alhmed, B. I., Yusuf, S. R., Yusuf, A. U., \& Aliyu, M. (2007). Comparative efficacy of different concentrations of some promising insecticides to the control of Podagrica spp (Coleoptera: chrysomelidae) on Okra (Abelmoschus esculentus (L.) Moench), J. Agric. Sc., 6, 31-34.

Anaso, E. C. (2003). Cost benefits of spraying sole and intercropped Okra with neem seed extracts and deltamethrin in the Nigeria Sudan savannah. Agric. Environ., 4, 122-123.

Araiptsas, P. (2008). Identification and quantification of polyphenolic compound from Okra seeds and skins. Food chem. 110, 1041-045.

Eberhard, B. (1978). Crop pests in Tanzania and their control. Germany Agency for Technical Cooperation, Ltd (GTZ). p.77.
Egwuatu, R. I. (1982). Field trial with systemic and contact insecticides for the control of Prodagrica spp. (Coleoptera: chrysomelidae) on Okra. Tropical pests management, 28(2), 115-121.

Emosairue, S. O. and Ukeh, D. A. E. I. (1997). Field trial of neem products for the control of Okra flea beetles (Podagrica spp.) in south-eastern Nigeria. Global J. Pure Appl. Sci., 3,13-19.

Ezue. M. I. (1978). An Introductory Economic Entomology for Nigeria. Ethiope publishing Corporation, Ring Road, Benin City, Nigeria. p. 88.

GenStat Release 10.3DE (2011). Discovery Edition 4 VSN International Ltd. Rothamsted Experimental Station, Howel, Hempstead, UK.

Huang, Z., Wang, B., Eave, P. H., Shikang, J. M., \& Pace, R. D. (2007). Phenolic compound profile of selected vegetables frequently consumed by Africa Americans in the south east United states. Food chem.103, 1395-1402.

Ibekwe, H. N., Nwanguma, E. I., \& Nworie, H. E. (2011). Efficacy of Selected Insecticides for Insect Pest Control of Fluted pumpkin, Telfairia occidentalis Hook. in South-eastern Nigeria. Nigerian Journal of Horticultural Science, 6, 27-31.

Izuogu, N. B., Oyedunmade, E. E. A., Olabiyi, T. I., Oluwatayo, I. I., \& Abolusoro, S. A. (2011). Control of Nematode pests of Okra (Abelmoschus esculentus L. Moench) using two plant materials and carbofuran. Nigerian Journal of Horticultural Science, 16, 33-40.

Kuchare, K., \& Holtchmuth, G. J. (2003). Okra Production in Florida. A handbook produced by Food and Agricultural Science, University of Florida Press, USA.

Lutsinger, J. A., \& Moody, K. (1976). Integrated Pest Management in multiple cropping Edition M. Stell. American society of Agronomy Madison Wisconsin ASA sp. Publication No. 273.

Mohammed-Ahmed, M. M. (2000). Studies on the control of insect pests in vegetables (Okra, vegetable and onion) in Sudan with special reference to neem preps. Ph. D. dissertation University of Glessen, Germany.

Nwadialor, B. E. (1989). Soil Landscaping Relationship in the Udi -Nsukka Plateau Catenna, pp. 1187.

Obeng-ofori, D., \& Sakey, J. (2003). Field Evaluation of unisynthetic insecticides for the management of insect pests of Okra (Abelmoschus esculentus (L) Moench) in Ghana. Ethiopian Journal of Science, 26, 145-150.

Obi, I. U. (2002). Statistical Methods of Detecting Differences between Treatment Means. Enugu SNAAP Press Ltd. p.38.

Odebiyi, J. A., Osisanya, E., \& Tayo, T.O. (1981). Assessment of damage caused by leaf eating beetles (Podagrica spp.) on Okra in South-western Nigeria. African Journal of Agricultural science, 8, 103-112.

Ogbalu, O. K., \& Ekweozo, I. K. E. (2002). The distribution of okra flea beetle on three varieties of Okra in Traditional farms of the Niger Delta. Trop. Sci., 42, 52-56.

Porter, G. I. (2000). Taxonomy of flowering plants. Freeman and Germany Ltd.

Raros, R. S. (1974). Crop protection with carbofuran and its efficacy on Soil and litter associated mites and Collembolan. Davoc city, 8-10 May, 1974.

Steel, G., \& Torrie, J. H. (1980). Procedure of Statistics. Biometrical Approach $2^{\text {nd }}$ edition. New York. Megraws Hill Box calpery Inc. p.633.

Thul, S. R., Patil, R. S., \& Mule R. S. (2009). Field efficacy of some pesticides against flea beetle, Podagrica spp (Coleopteran: chrysomelidae) in testing Okra. J. Maharashitra Agric. Uni., 34, 57-59. 
Uguru, M. I. (2011). Crop Production Tools, Techniques and practices. Falladu Publishing Company. Nsukka, Pp. 55-58.

Ukoima, H. N., \& Oka, A. (2006). Use of some biopesticides in controlling pests and diseases of Okra (Abelmoschus esculentus). Field Environ. Ecol., 24, 773-776.

Uthamamy, S. (1977). Insecitidal control of pests and yellow vein mosaic disease of bhindi. Science and Culture, 4(11), 510-512.
Vanlommel, S., Duchateau, L. And Coosemans, J. (1996). The effect of Okra mosaic virus and beetle damage on Yield of Okra cultivars. African. Crop Science Journal, 4, 71-77.

Zook, A. N. (2006). All about Okra. Eds: Army Kaizer and Haroun Hallack. Wisconson University Press. 